\title{
Distribution of organochlorine pesticides in atmospheric air of Tamilnadu, southern India
}

\author{
S. Srimurali • S. Govindaraj · S. Krishna Kumar • \\ R. Babu Rajendran
}

Received: 3 August 2013/Revised: 13 December 2013/Accepted: 12 March 2014/Published online: 3 May 2014

(C) Islamic Azad University (IAU) 2014

\begin{abstract}
Passive air sampling was performed for urban, suburban, coastal, and agriculture air during April 2009January 2010 in Tamilnadu, southern India, to know the distribution and fate of organochlorine pesticides (OCPs) residues. Exposed polyurethane foam samples ( $30 \pm 2$ days) were soxhlet extracted, and the extracts were analyzed using gas chromatography-mass spectrometric method. The total concentrations of 13 OCPs were in the range of not detected (ND) $-41,400 \mathrm{pg} / \mathrm{m}^{3}$. Dichlorodiphenyltrichloroethane, dichlorodiphenyldichloroethylene, heptachlor, and mirex were found predominant during monsoon season. The elevated $\alpha / \gamma$ isomer ratio of hexachlorocyclohexane (HCH) (5.03) during summer revealed fresh/recent usage of $\mathrm{HCH}$ in coastal area. Dichlorodiphenyltrichloroethane ratio shows its fresh application in all the locations during monsoon season, which probably used to contain the diseases causing vectors. Detection of banned pesticides, such as aldrin, dieldrin, and heptachlor in air, indicating their illegal usage/or from old source. Furthermore, mirex, an unregistered pesticide in India, is being reported for the first time in air. More importantly, the obtained information will be used as a valuable baseline data for the management of atmospheric OCPs in future.
\end{abstract}

Electronic supplementary material The online version of this article (doi:10.1007/s13762-014-0558-3) contains supplementary material, which is available to authorized users.

S. Srimurali · S. Govindaraj · S. Krishna Kumar .

R. Babu Rajendran $(\bowtie)$

Department of Environmental Biotechnology, School of

Environmental Sciences, Bharathidasan University,

Tiruchirappalli 620024, Tamil Nadu, India

e-mail: ramaswamybr@gmail.com
Keywords Air pollution - Organochlorine pesticides . Passive air sampling · Gas chromatography-mass spectrometry $\cdot$ India

\section{Introduction}

Though organic farming is gaining importance, the application of synthetic pesticides is still practiced in agriculture and for sanitation purposes, pesticide residual prevalence in environmental matrices is an all time environmental concern. The organochlorine pesticides (OCPs) are reported to be associated with soil, water, air, and biota as toxic contaminants (Kang et al. 2001). Their physical/chemical properties including hydrophobicity, lipophilicity, and moderate vapor pressure make them persistent in the environment. OCPs are of special concern due to its toxicity, long-range transport, and potential to bioaccumulate (UNECE, United Nations Economic Commission for Europe 1998).

The worldwide usage of herbicides, insecticides, and fungicides is 49.6, 26.2, and $19.5 \%$, respectively (Merrington et al. 2002). OCPs are mostly associated with soil but being semi volatile, they disperse in air and get partitioned between gas and particulate phases based on the molecular weight (Sanusi et al. 1999; Sauret et al. 2008). Wind circulation plays a major role in transport and deposition of OCPs around the world. Despite the ban of most OCPs, higher atmospheric levels are still reported in many parts of the world (He and Balasubramanian 2009; Zheng et al. 2010). Further, their trace quantification in distant polar environment signifies its long-range transport and bioaccumulation scenario. Recently, Chakraborty et al. (2010) reported high level of OCPs in the atmosphere of Indian cities such as Agra, Bangalore, Chennai, Goa, 
Mumbai, New Delhi, and Kolkata. Devi et al. (2011) also reported OCPs from high altitude ambient air (at Manipur) in India, with the signature of dichlorodiphenyltrichloroethanes (DDTs).

In India, some of the banned pesticides are permitted in agriculture and vector control activities, for example, DDT is still used for malaria control (Pozo et al. 2011). Similarly, technical hexachlorocyclohexane $(\mathrm{HCH})$ was banned in 1997, but the government of India was permitted to manufacture and use the $\gamma-\mathrm{HCH}$ in the name of lindane. Very recently, endosulfan, a booming teratogen is banned only in few states of India. In Tamilnadu state, $70 \%$ of populations are engaged in agriculture and allied activities to support its economy. It has the cultivated land of around 5,843,000 $\mathrm{hm}^{2}$, which includes main crops such as vegetables, grains and pulses, turmeric, sugarcane, and oilseeds. The pesticides usage is so intense in cultivation, and even the seeds to be sown are treated (TNAU, Tamil Nadu Agricultural University 2009).

The present study was carried out to understand the spatial and seasonal distribution of 13 OCPs in the atmospheric air covering urban, suburban, agriculture, and coastal areas of Tamilnadu, southern India and to find their possible sources. The samples were collected during summer, premonsoon, and monsoon seasons of the year
2009-2010. The main goal was to establish the baseline data for future monitoring studies.

\section{Materials and methods}

Study area

Tamilnadu state is located in southernmost part of India and has a population of about $72,138,958$ according to Census of India (2011), and the state is witnessing rapid industrialization, urbanization, and population growth. For the present study, air samplers were deployed at 32 sites covering urban (13), suburban (7), coastal (8), and agricultural (4) locations. The sampling was performed during summer, premonsoon, and monsoon seasons of 2009-2010. The polyurethane foams (PUFs) were exposed for $30 \pm 2$ days. Details of sampling locations, and geographical co-ordinates and altitude were shown in Fig. 1 and Table S1 (supporting data), respectively.

\section{Passive air sampler}

The passive air sampler was indigenously assembled with the available components as per the specifications given in Shoeib and Harner (2002). The sampler consists of two
Fig. 1 Map showing the sampling ( $n=$ number of sites) locations

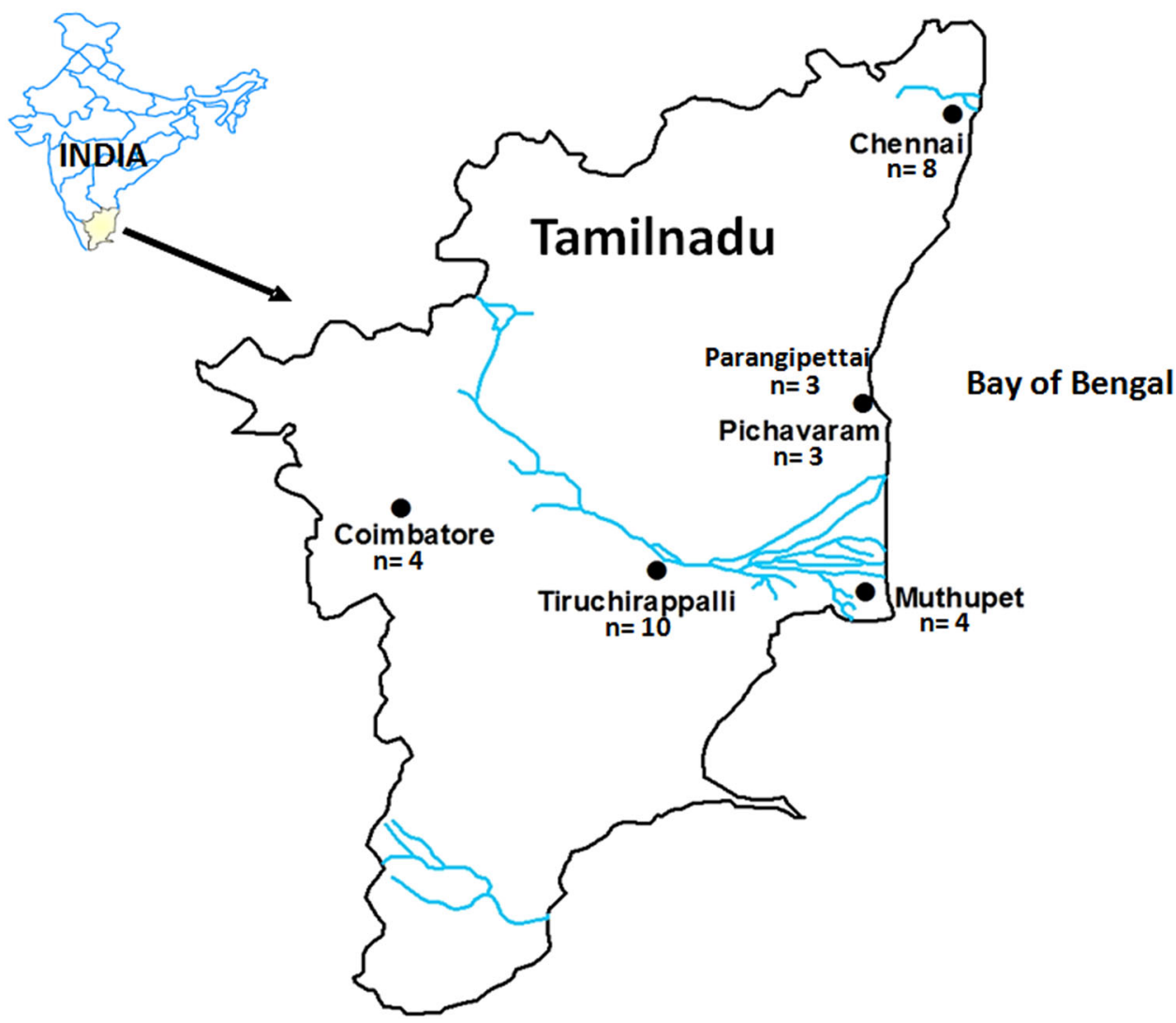


domed stainless steel chambers aligned in central axis, to house the PUF disk $(15 \mathrm{~cm}$ diameter, $1.35 \mathrm{~cm}$ thick, $0.0176 \mathrm{~g} / \mathrm{cm}^{3}$ density). The stainless steel chambers provide protection against sunlight, UV rays, direct precipitation, and particle deposition, and also maintain constant wind flow. PUFs were prewashed (methanol) and cleaned by soxhlet extraction ( $6 \mathrm{~h}$ using acetone: $n$-hexane) before installation. The exposed PUFs were wrapped in two layers of aluminum foil, labeled, placed in ziplock polythene bag, and transported to the laboratory in cold condition and kept at $-18{ }^{\circ} \mathrm{C}$ until extraction.

Standards and chemicals

Organochlorine pesticides standards $(\alpha-\mathrm{HCH}, \beta-\mathrm{HCH}, \gamma-$ $\mathrm{HCH}, \mathrm{HCB}$, aldrin, dieldrin, $p, p^{\prime}-\mathrm{DDE}, o, p^{\prime}-\mathrm{DDE}, p, p^{\prime}-$ DDD, $o, p^{\prime}$-DDD, $p, p^{\prime}$-DDT, and mirex) and internal standard phenanthrene $\mathrm{D}_{12}$ were procured from AccuStandard (New Haven, USA) with a purity of 97.6-100\%. Solvents such as n-Hexane, dichloromethane (DCM), and acetone of GC grade were from Thermo Fisher Scientific India Pvt. Ltd. (Mumbai, India). Silica gel (60-120 mesh size), sodium sulfate (anhydrous), and glass wool were obtained from Himedia Laboratory Pvt. Ltd. (Mumbai, India). All glassware were cleaned in series with soap solution, tap water, hydrochloric acid, deionised water, and acetone, and kept in hot air oven at $250{ }^{\circ} \mathrm{C}$ for overnight before use.

\section{Sample extraction}

The exposed PUF disk was extracted for OCPs based on the method of Buehler et al. (2001) with minor modifications. Briefly, each PUF was extracted using soxhlet for $6 \mathrm{~h}$ using $200 \mathrm{~mL}$ of acetone and hexane (1:1). Then, the extract was concentrated to about $1 \mathrm{~mL}$ using rotary vacuum evaporator (Buchi R-210, Switzerland) and cleaned up by preconditioned silica gel column $(1.3 \mathrm{~cm}$ dia. $\times 24 \mathrm{~cm}$ length). After loading the extract, the OCPs were eluted with $25 \mathrm{ml}$ of $n$-hexane: DCM (1:1) and condensed the eluate to about $1 \mathrm{~mL}$ using rotary vacuum evaporator, collected in a glass vial and further concentrated to $1 \mathrm{~mL}$ under a gentle stream of nitrogen gas. The extract vials were stored at $-4{ }^{\circ} \mathrm{C}$ until gas chromatograph-mass spectrometer (GC-MS) analysis.

\section{Instrumental analyses}

The qualitative and quantitative determination of OCPs was performed by GC-MS (QP2010; Shimadzu), equipped with auto injector (AOC-20i). The analytes separation was performed in a $60 \mathrm{~m} \times 0.25 \mathrm{~mm}$ I.D. $\times 0.25 \mu \mathrm{m}$ film thickness Rtx column (Restek, PA, USA), and helium was used as a carrier gas at a flow rate of $2 \mathrm{~mL} / \mathrm{min}$. The column temperature was programed as $100-150{ }^{\circ} \mathrm{C}$ at $10{ }^{\circ} \mathrm{C} /$ $\min$, to $250{ }^{\circ} \mathrm{C}$ at $5{ }^{\circ} \mathrm{C} / \mathrm{min}$, to $280{ }^{\circ} \mathrm{C}$ at $2{ }^{\circ} \mathrm{C} / \mathrm{min}$, finally to $320^{\circ} \mathrm{C}$ at $5^{\circ} \mathrm{C} / \mathrm{min}$, and hold for $10 \mathrm{~min}$. About $1 \mu \mathrm{l}$ of the extract was injected into the injection port (at $250{ }^{\circ} \mathrm{C}$ ) using auto injector. The mass spectrometer was operated in SIM mode, and the ion source temperature was kept at $230{ }^{\circ} \mathrm{C}$. The electron ionization (EI) unit was operated at $70 \mathrm{eV}$ and at an emission current of $60 \mu \mathrm{A}$. Full-scan data were obtained in a mass range of $\mathrm{m} / \mathrm{z}$ 35-500. Scanning interval and SIM sampling rate were 0.5 and $0.2 \mathrm{~s}$, respectively.

Quality control and quality assurance

Quality control/quality assurance was performed throughout the analyses. Field and laboratory blanks were performed for each batch of PUF analysis. The blanks (precleaned PUF disks) were extracted and analyzed to confirm their purity. To obtain the recovery percentage, the cleaned unexposed PUFs were spiked with known concentrations of pesticide mixture (13 OCPs), extracted, and cleaned up by silica gel and analyzed as that of the sample. The calibration of OCPs standard was performed in the liner range of $1-200 \mathrm{ng} / \mathrm{mL}$. The calibration curves showed good linearity, with correlation coefficient $\left(r^{2}\right)$ of $>0.997$. The QA/QC criteria, such as analytes precision, recovery, LOD, and LOQ, were given in Table S2 (supporting data). We regularly took part in interlaboratory calibration exercise organized by International Atomic Energy Agency (IAEA, International Atomic Energy Agency 2012) to check the standard of our laboratory.

\section{Results and discussion}

The minimum (min), maximum ( $\max$ ), mean, and median concentration of OCPs in atmospheric air of Tamilnadu, southern India, was listed in Table S3 (supporting data). The concentration of total HCHs (sum of $\alpha, \beta$, and $\gamma$ isomers) ranged from not detected (ND) to $1,232 \mathrm{pg} / \mathrm{m}^{3}$ (mean $257 \mathrm{pg} / \mathrm{m}^{3}$; median $47 \mathrm{pg} / \mathrm{m}^{3}$ ). The concentration of total DDT (sum of $o, p^{\prime}$-DDE, $p, p^{\prime}$-DDE, $o, p^{\prime}$-DDD, $p, p^{\prime}$-DDD, and $p, p$-DDT) ranged from $\mathrm{ND}$ to $2,468 \mathrm{pg} / \mathrm{m}^{3}$ (mean $345 \mathrm{pg} / \mathrm{m}^{3}$; median $206 \mathrm{pg} / \mathrm{m}^{3}$ ). Among other OCPs, aldrin ranged from $\mathrm{ND}$ to $283 \mathrm{pg} / \mathrm{m}^{3}$ (mean $55 \mathrm{pg} / \mathrm{m}^{3}$; median $30 \mathrm{pg} / \mathrm{m}^{3}$ ), dieldrin from ND to $335 \mathrm{pg} / \mathrm{m}^{3}$ (mean $78 \mathrm{pg} / \mathrm{m}^{3}$; median $68 \mathrm{pg} / \mathrm{m}^{3}$ ), heptachlor from ND to $1,012 \mathrm{pg} / \mathrm{m}^{3}$ (mean $220 \mathrm{pg} / \mathrm{m}^{3}$; median $237 \mathrm{pg} / \mathrm{m}^{3}$ ), HCB from ND to $613 \mathrm{pg} / \mathrm{m}^{3}$ (mean $134 \mathrm{pg} / \mathrm{m}^{3}$; median $96 \mathrm{pg} / \mathrm{m}^{3}$ ), and mirex from ND to $40,155 \mathrm{pg} / \mathrm{m}^{3}$ (mean $4,609 \mathrm{pg} / \mathrm{m}^{3}$; median $\left.2,432 \mathrm{pg} / \mathrm{m}^{3}\right)$. 


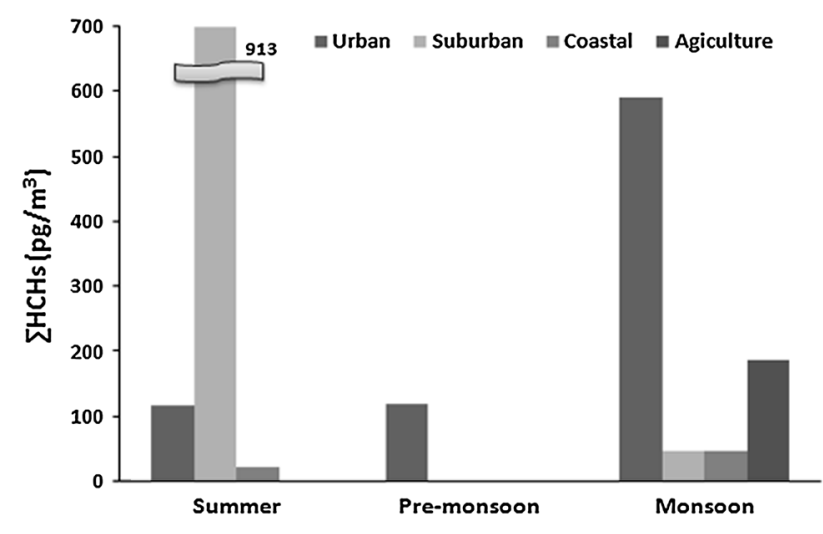

Fig. 2 Seasonal variation in $\sum \mathrm{HCHs}$ in atmospheric air

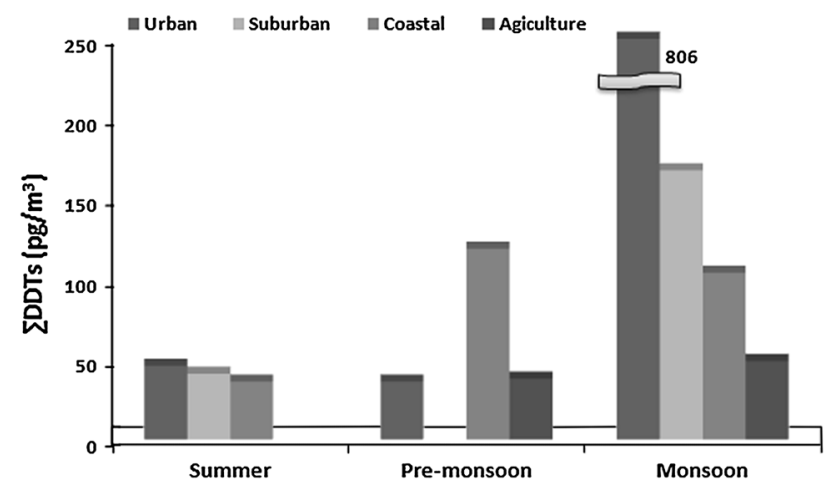

Fig. 3 Seasonal variation in $\sum D D T$ s in atmospheric air

OCPs seasonal variation

The concentration of total OCPs during monsoon season is one to two orders of magnitude higher than in summer and premonsoon seasons. Importantly, the season-wise comparison revealed that $\mathrm{HCH}$ isomers were predominant in summer and monsoon seasons (Fig. 2), whereas DDTs were prevalent in all the seasons; however, the trend was decreasing in the order of monsoon $>$ premonsoon $>$ summer seasons (Fig. 3).

\section{Summer season}

In summer, only seven OCPs were detected namely $\alpha$ $\mathrm{HCH}, \beta-\mathrm{HCH}, \gamma-\mathrm{HCH}, p, p$ '-DDE, aldrin, dieldrin, and heptachlor. The levels of OCPs were found decreasing toward suburban, urban, coastal, and agriculture areas (Table 1). The total $\mathrm{HCH}$ (sum of $\alpha, \beta, \gamma$ ) ranged from ND to $1,162 \mathrm{pg} / \mathrm{m}^{3}$. The technical mixture of $\mathrm{HCH}$ production was stopped in India by 1997 (Gupta 2004); however, the detection of $\alpha$ - and $\beta$ - $\mathrm{HCH}$ at high concentration shows the technical mixture usage and/or its presence in lindane as impurity. Further, there is also a possibility of photochemical transformation of $\gamma-\mathrm{HCH}$ to $\alpha-\mathrm{HCH}$ in the atmosphere during long-range transport (Barrie et al. 1992). The technical grade mixture used in Asian countries consists of $\alpha$-isomer (60-70\%) at higher ratio than $\beta, \gamma$, and $\delta$ ratios (5-12\%) (Kutz et al. 1991; Iwata et al. 1994).

Among the $\mathrm{HCHs}, \beta-\mathrm{HCH}$ was predominantly found $\left(913 \mathrm{pg} / \mathrm{m}^{3}\right)$ in coastal air. The concentration of $\beta-\mathrm{HCH}$ is due to its persistent and least reactive nature among the four $\mathrm{HCH}$ isomers; furthermore, it has low solubility and slow decomposition (Mishra et al. 2012). The $\beta-\mathrm{HCH}$ prevalence can also be due to the long-range transport, which has half-life time of 100 days (Willett et al. 1998). Hayes (1982) suggested the isomerization of $\gamma-\mathrm{HCH}$ to $\beta$ $\mathrm{HCH}$ in seawater and sediment, so flux from seawater to surrounding air could be the reason for the elevated levels observed in this study. Previously Babu Rajendran et al. (1999) reported higher levels of $\mathrm{HCHs}$ residues (up to $35,000 \mathrm{pg} / \mathrm{m}^{3}$ ) in atmospheric air of Parangipettai in Tamilnadu, southern India, which is much higher than the present study. Similar to our results, $\beta-\mathrm{HCH}$ was reported at higher level in coastal air at Goa and Mumbai in west coast of India (Iwata et al. 1994). However, Devi et al. (2011) reported low concentration of $\beta-\mathrm{HCH}$ (up to $38 \mathrm{pg} / \mathrm{m}^{3}$ ) in Waithou Mountain, northeastern India, than other HCHs (up to $176 \mathrm{pg} / \mathrm{m}^{3}$ ).

Among DDTs, only $p, p^{\prime}$-DDE was detected (up to $46 \mathrm{pg} / \mathrm{m}^{3}$ ) during summer season (Table 1) and this could be the result of conversion of DDT to DDE in the atmosphere and further DDE is the most stable form of DDT (Atlas and Giam 1988). The volatilization of soil residues may also a reason for OCPs diagnosis in summer. In particular, occurrence of aldrin and dieldrin may be due to its usage as soil insecticides in corn, potato, and other crops and also as termite killer in wooden structures (Ozcan and Aydin 2009).

\section{Premonsoon season}

In premonsoon, the average concentrations of $\Sigma_{13}$ OCPs in coastal, urban, and agriculture air were 1,040, 490, and $90 \mathrm{pg} / \mathrm{m}^{3}$, respectively. However, OCPs were not detected in air from suburban area. Among $\mathrm{HCHs}$, only $\gamma$-HCH was detected in urban location $\left(253 \mathrm{pg} / \mathrm{m}^{3}\right)$. In case of DDT, $p, p^{\prime}$ - DDE was highly detected up to $175 \mathrm{pg} / \mathrm{m}^{3}$ at coastal region with $\Sigma$ DDTs constitute higher level $\left(237 \mathrm{pg} / \mathrm{m}^{3}\right)$ than all other locations. In the present study, higher level of DDE implies recent past or continuing usage of DDT in coastal and surrounding areas, probably for vector control activities such as malaria,(Pozo et al. 2011), and agriculture as well. Since, $p, p^{\prime}$-DDE is more stable end product of DDT (Pandey et al. 2011); it may also account for higher detection than DDT in coastal area. In urban air also, all the metabolites of DDT were detected (Table 1), suggesting its ubiquitous prevalence. The detection of aldrin and dieldrin 


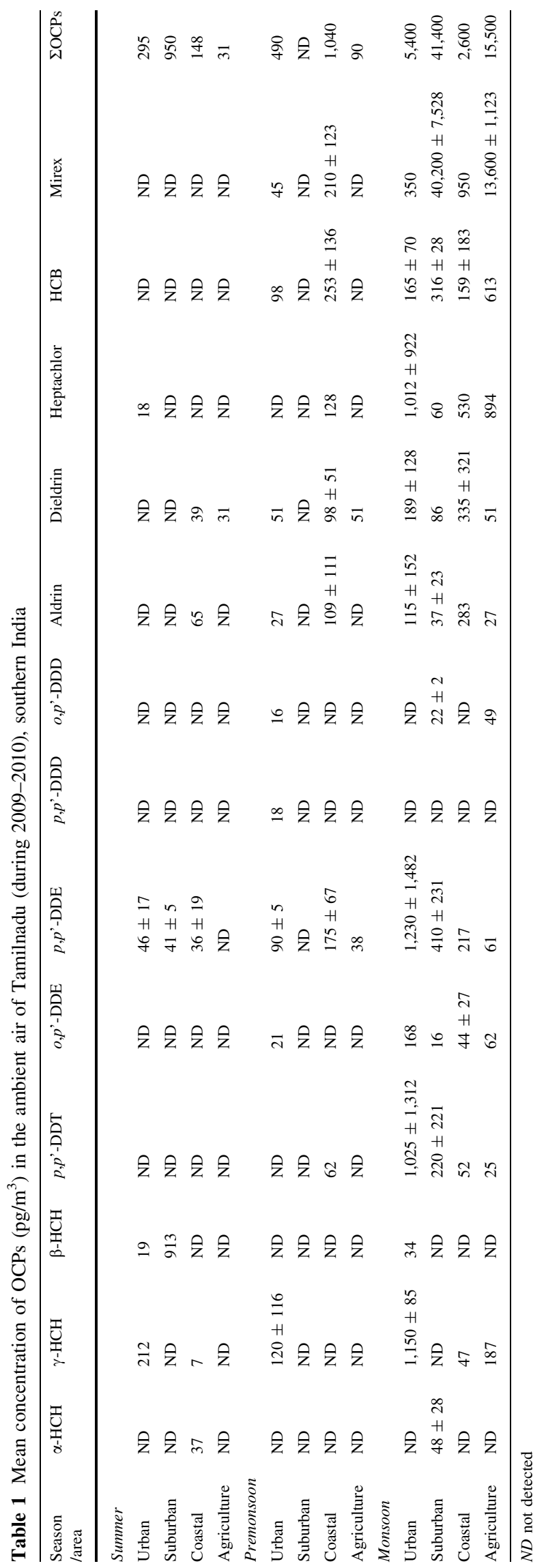

implies their illegal usage since these pesticides were banned in India from 1990 onwards (IPEN, International POPs Elimination Network 2006).

HCB was the highest detected OCP in premonsoon with a maximum concentration of $253 \mathrm{pg} / \mathrm{m}^{3}$ at coastal area. Other than coastal area, it was quantified only in urban air $\left(98 \mathrm{pg} / \mathrm{m}^{3}\right)$. Although it is a banned OCP in several countries (including India), the detection again reminds its illegal usage as fungicide in seed treatment (Barber et al. 2005), etc., or its occurrence as co-contaminant in pesticide formulations such as lindane, (ATSDR, Agency for Toxic Substances and Disease Registry 2002). Heptachlor, another banned pesticide was recorded only at coastal air $\left(128 \mathrm{pg} / \mathrm{m}^{3}\right)$; however, its use as insecticide is well known and has been earlier reported in India (Pozo et al. 2011). Mirex was widely detected in the range of $45-221 \mathrm{pg} / \mathrm{m}^{3}$ in all areas, and it is the second highest OCP detected; however, its use is not clearly stated in any of the previous literature and hence unable to point the exact source.

\section{Monsoon season}

The monsoon season showed highest OCPs in atmospheric air than in other two seasons; the levels are found in the order of suburban $>$ agriculture $>$ urban $>$ coastal air (Table 1). The mean $\mathrm{HCH}$ concentrations ranged from 47 to $1,384 \mathrm{pg} / \mathrm{m}^{3}$ with $\gamma-\mathrm{HCH}$ as the predominant isomer quantified up to $1,150 \mathrm{pg} / \mathrm{m}^{3}$. The presence of $\alpha$ - and $\beta$ $\mathrm{HCH}$ in suburban and urban locations with a concentration $\leq 50 \mathrm{pg} / \mathrm{m}^{3}$ may be due to its mere existence as co-contaminants in pesticides. The highest detection of $\gamma-\mathrm{HCH}$ $\left(1,150 \mathrm{pg} / \mathrm{m}^{3}\right)$ in urban location may be due to its increased usage in vector control spray (fly, flea, cockroach, mosquito, bed bug, and beetle populations). Also, it is used in pharmaceutical products to kill lice and scabies (Ministry of Agriculture, India 2008). Nevertheless, in agriculture also lindane is mostly used to control pests in cotton, sugarcane, pumpkin, cabbage, onion, etc., in Tamilnadu (Ministry of Agriculture, India 2008). Similarly, Pozo et al. (2011) reported high concentrations (up to $4,000 \mathrm{pg} / \mathrm{m}^{3}$ ) of $\gamma-\mathrm{HCH}$ in air close to agriculture activities near Delhi, India.

Among DDTs, $p, p^{\prime}$-DDE and $p, p^{\prime}$-DDT were detected up to 1,230 and $1,025 \mathrm{pg} / \mathrm{m}^{3}$, respectively, in urban locations. As of other OCPs, heptachlor $\left(60-1,012 \mathrm{pg} / \mathrm{m}^{3}\right)$ and HCB $\left(165-613 \mathrm{pg} / \mathrm{m}^{3}\right)$ were also highly detected. Heptachlor is a banned insecticide (including India), which is used for controlling soil insect and termites, grasshoppers, and malaria-carrying mosquitoes (Pozo et al. 2011). Brubaker and Hites (1998) reported that HCB has relatively high vapor pressure and low water solubility, so it has long atmospheric half-life of 940 days. Also, the presence of HCB may be due to industrial activities including pesticides and other chemicals manufacturing. Often, HCB is an 
impurity in pesticides used for agriculture (Bailey 2001). The mirex was found at higher levels than other OCPs in all the locations with the maximum mean concentration of $40,200 \mathrm{pg} / \mathrm{m}^{3}$ in suburban area, and the distribution pattern shows that mirex was predominant with $80 \%$ of total OCPs. In urban and coastal locations, the concentration did not exceed $1,000 \mathrm{pg} / \mathrm{m}^{3}$, whereas the suburban and agriculture locations showed higher levels and ranged from 13,600 to

Table 2 Diagnostic ratio of $p, p^{\prime}$-DDT/o, $p^{\prime}$-DDE, and $\alpha-\mathrm{HCH} / \gamma-\mathrm{HCH}$

\begin{tabular}{lll}
\hline Season/location & $p, p^{\prime}$-DDT/o, $p^{\prime}$ DDE & $\alpha-\mathrm{HCH} / \gamma-\mathrm{HCH}$ \\
\hline $\begin{array}{lll}\text { Summer } \\
\text { Coastal }\end{array}$ & NA & 5.03 \\
Premonsoon & & \\
Coastal & 0.36 & NA \\
Monsoon & & \\
Urban & 6.11 & NA \\
Suburban & 13.42 & NA \\
Coastal & 1.17 & NA \\
Agriculture & 0.41 & NA
\end{tabular}

NA not applicable
$40,200 \mathrm{pg} / \mathrm{m}^{3}$. Although it is not a registered pesticide in India (Central Insecticide Board 2012), its detection in all locations may be due to illegal usage as stomach insecticide, common insecticide and/or released while burning materials coated with flame retardants (Fisher 1999). However, official records/regulations pertaining the use of mirex as pesticide are not available. Further, mirex is known to be manufactured and used in the name of "Dechlorane, Cyclopentadiene, etc.," in formulation of fire retardants/ suppressants, which is used in plastics, rubber, paints, paper, and electrical products. It is also used as pesticides in agriculture in the name of Kepone (USEPA, United State Environment Protection Agency 2009). Apart from the atmospheric air in the present study, Bhuvaneshwari and Rajendran (2011) also reported elevated levels of mirex (up to $17,518 \mathrm{ng} / \mathrm{L}$ ) in the Cauvery (Kaveri) river water from Tamilnadu, India, confirming its undisclosed usage.

\section{Diagnostic ratio of DDTs and $\mathrm{HCHs}$}

In summer, the ratio of $\alpha-\mathrm{HCH} / \gamma-\mathrm{HCH}$ was 5.03 (Table 2) for coastal air and the value $>1$ indicates the fresh usage of

Table 3 Comparison of OCPs mean concentration $\left(\mathrm{pg} / \mathrm{m}^{3}\right)$ in air from Tamilnadu with Indian and global data

\begin{tabular}{|c|c|c|c|c|c|c|}
\hline Sampling sites & $\alpha-\mathrm{HCH}$ & $\gamma-\mathrm{HCH}$ & $p, p^{\prime}-\mathrm{DDT}$ & $p, p^{\prime}-\mathrm{DDE}$ & Year & Reference \\
\hline \multicolumn{7}{|l|}{ Tamilnadu, India } \\
\hline Urban (13 sites) & - & 650 & 1,025 & 68 & $2009-2010$ & Present study \\
\hline Suburban (7 sites) & 48 & - & 220 & 263 & $2009-2010$ & Present study \\
\hline Coastal (8 sites) & 36 & 27 & 57 & 177 & $2009-2010$ & Present study \\
\hline Agriculture (4 sites) & - & 187 & 25 & 50 & $2009-2010$ & Present study \\
\hline \multicolumn{7}{|l|}{ Tamilnadu, India } \\
\hline Chennai (urban) & 1,691 & 3,562 & 220 & 2,061 & 2008 & Zhang et al. (2008) \\
\hline Portnova (rural/coastal) & 410 & 686 & 387 & 161 & 2008 & Zhang et al. (2008) \\
\hline Cuddalore (rural) & 58 & 231 & 27 & 48 & 2008 & Zhang et al. (2008) \\
\hline Pondicherry (urban) & 167 & 437 & 55 & 89 & 2008 & Zhang et al. (2008) \\
\hline \multicolumn{7}{|l|}{ India } \\
\hline Manipur (urban) & 89 & 80 & 41 & 82 & 2009 & Devi et al. (2011) \\
\hline Manipur (rural) & 110 & 84 & 27 & 96 & 2009 & Devi et al. (2011) \\
\hline Kolkata (urban) & 513 & 625 & 124 & 608 & 2008 & Zhang et al. (2008) \\
\hline Agriculture (7 sites) & 292 & 812 & 931 & 247 & 2006-2007 & Pozo et al. (2011) \\
\hline New Delhi (urban) & 298 & 3,104 & 34 & 261 & 2006-2007 & Chakraborty et al. (2010) \\
\hline Kolkata (urban) & 712 & 1,067 & 61 & 268 & 2006-2007 & Chakraborty et al. (2010) \\
\hline \multicolumn{7}{|l|}{ Other country } \\
\hline Asia & $4-145$ & BDL-68 & BDL-131 & BDL-58 & 2004-2005 & Pozo et al. (2006) \\
\hline Africa & BDL-117 & $0.4-67$ & BDL & BDL-2 & 2004-2005 & Pozo et al. (2006) \\
\hline Europe & $<14-100$ & $9-390$ & - & $<0.4-2.5$ & 2002 & Jaward et al. (2005) \\
\hline Japan & - & - & $4.4-146$ & $1.62-544$ & 2004 & Jaward et al. (2005) \\
\hline Singapore & - & - & $<1.9-16$ & $<1.5-10$ & 2004 & Jaward et al. (2005) \\
\hline South Korea & - & - & $<1.9-20$ & $<15-25$ & 2004 & Jaward et al. (2005) \\
\hline
\end{tabular}

$B D L$ below detection limit 
technical mixture rather than lindane and may be due to effective long-range transport of $\mathrm{HCHs}(\gamma-\mathrm{HCH})$ from other region (Sofuoglu et al. 2004). Absence of $\mathrm{HCH}$ in summer season (noncropping season) at agricultural area may be due meager or no usage of pesticides. In premonsoon, the observed $p, p^{\prime}$-DDT/ $/, p^{\prime}$-DDE ratio for coastal area of 0.36 indicates the past (long term) source of DDT and in monsoon, it was found between 0.41 and 13.7 (Table 2), indicating the fresh usage of DDT all over Tamilnadu province (India). As the insect menace and mosquito breeding are high during monsoon season, the obtained results clearly indicate the proportional usage of DDT to control mosquitoes, etc. The global production of DDT during 2005 was 6,269 metric tons (Klanova et al. 2009), but in India, through National Vector Borne Disease Control Program, 4,930 metric tons of DDT was provided to states during 2008 for vector control (Toxic Links Fact Sheet 2011).

Comparisons of OCPs in Tamilnadu with national (India) and global data

In present study, $\alpha-\mathrm{HCH}$ concentration is lower than previous reports at national and international levels (Table 3). Further, the urban $\gamma$-HCH levels (up to $650 \mathrm{pg} / \mathrm{m}^{3}$ ) were well below the previous report of Zhang et al. (2008) for Chennai $\left(3,562 \mathrm{pg} / \mathrm{m}^{3}\right)$, but the concentration was comparable with other urban locations in India (Zhang et al. 2008; Devi et al. 2011) and other countries (Asia, Africa, Europe, Japan, Singapore, and South Korea) (Pozo et al. 2006; Jaward et al. 2005). The $p, p^{\prime}$ DDT detected in urban $\left(1,025 \mathrm{pg} / \mathrm{m}^{3}\right)$ and suburban $\left(220 \mathrm{pg} / \mathrm{m}^{3}\right)$ areas was the highest reported concentration in India next to Zhang et al. (2008) for Chennai. The atmospheric concentration of OCPs in southeast Asian region (Singapore and South Korea) (Jaward et al. 2005) were lower than our study. The $p, p^{\prime}$ DDE levels in this study were lower than earlier levels for urban India (Table 3); Zhang et al. (2008) reported a high concentration $(2,061 \mathrm{pg} /$ $\mathrm{m}^{3}$ ) at Chennai, India. The $p, p^{\prime}$-DDE levels in Africa, Europe, Singapore, and South Korea were quite lower than the concentrations observed in India (Table 3). The past (Zhang et al. 2008) and present studies in India signify that $\gamma-\mathrm{HCH}$ usage is somehow dwindling; however, DDT levels were found higher or comparable than the past observations, which corroborate the dependence on DDT in India is still high to contain mosquito menace.

\section{Conclusion}

The PUF passive air sampler was used to determine the spatial and temporal distribution of atmospheric OCPs in Tamilnadu, southern India. The $\Sigma_{13}$ OCPs were in the range of ND-41,400 $\mathrm{pg} / \mathrm{m}^{3}$ with more contribution of $\gamma-\mathrm{HCH}$, heptachlor, and mirex. In urban locations, $p, p^{\prime}$ DDT and $p, p^{\prime}$ DDE were detected $>1,000 \mathrm{pg} / \mathrm{m}^{3}$ indicate its present usage. In suburban area, none of the OCPs were detected during premonsoon. Whereas, in monsoon season, high OCPs were detected and it signifies the usage of pesticide in both agriculture as well as non agricultural applications such as disease-causing vector control practices. Detection of banned pesticides such as aldrin, heptachlor, and dieldrin reveals their illegal use and/or long-range transport from other regions. Mirex (nonregistered pesticide) was quantified at elevated levels during monsoon season, and their occurrence may be due to its use as flame retardants in consumer products and subsequent release during burning, etc. According to this study, atmospheric environment in Tamilnadu is contaminated by diverse OCPs, suggesting the need to take measures to reduce their levels, and further, this forms an important baseline data for future national regulation for OCPs usage/emission.

Acknowledgments We are obliged to thank University Grants Commission (Project No. F.34-75/2008 dated December 30, 2008), New Delhi, for the financial support to carryout this study. We are also grateful to the United Nations University, Japan and Shimadzu Corporation, Japan, for the GC-MS facility extended through POPs Monitoring project by which the analyses were made.

\section{References}

Atlas E, Giam CS (1988) Ambient concentration and precipitation scavenging of atmospheric organic pollutants. Water Air Soil Pollut 38(1-2):19-36

ATSDR, Agency for Toxic Substances and Disease Registry (2002) Toxicological profile for DDT, DDD, and DDE. http://www. atsdr.cdc.gov/toxprofiles/tp35.pdf. Accessed 5 Oct 2012

Babu Rajendran R, Venugopalan VK, Ramesh R (1999) Pesticide residues in air from coastal environment, South India. Chemosphere 39(10):1699-1706

Bailey RE (2001) Global hexachlorobenzene emissions. Chemosphere 43(2): 167-182

Barber JL, Sweetman AJ, van Wijk D, Jones KC (2005) Hexachlorobenzene in the global environment: emissions, levels, distribution, trends and processes. Sci Total Environ 349(1-3):1-44

Barrie LA, Gregor D, Hargrave B, Lake R, Muir D, Shearer R, Tracey B, Bidleman T (1992) Arctic contaminants: sources, occurrence and pathways. Sci Total Environ 122(1-2):1-74

Bhuvaneshwari R, Rajendran RB (2011) GCMS determination of organochlorine pesticides (OCPs) in fish from river Cauvery and Veeranam Lake. J Chem 9(4):2346-2353

Brubaker WW Jr, Hites RA (1998) OH reaction kinetics of gas-phase $\alpha$ - and $\gamma$-hexachlorocyclohexane and hexachlorobenzene. Environ Sci Technol 32(6):766-769

Buehler SS, Basu I, Hites RA (2001) A comparison of PAH, PCB, and pesticide concentrations in air at two rural sites on Lake Superior. Environ Sci Technol 35(12):2417-2422

Census of India (2011) Government of India website for census. http://www.census2011.co.in/census/state/tamil+nadu.html. Accessed 5 Oct 2012

Central Insecticide Board (2012) List of pesticides/pesticides formulations banned in India. http://cibrc.nic.in/list_pest_bann.htm. Accessed 10 Oct 2012 
Chakraborty P, Zhang J, Li J, Xu Y, Liu X, Tanabe S, Jones KC (2010) Selected organochlorine pesticides in the atmosphere of major Indian cities: levels, regional versus local variations, and sources. Environ Sci Technol 44(21):8038-8043

Devi NL, Qi S, Chakraborty P, Zhang G, Yadav IC (2011) Passive air sampling of organochlorine pesticides in a northeastern state of India. Manipur. J Environ Sci 23(5):808-815

Fisher B (1999) Most unwanted persistent organic pollutant. Environ Health Perspect 107(1):A18-A25

Gupta PK (2004) Pesticides exposure: Indian scene. Toxicology 198(1-3):83-90

Hayes WJ Jr (1982) Pesticides studied in man. Williams \& Wilkins, Baltimore/London, p 398

He J, Balasubramanian R (2009) Semi-volatile organic compounds (SVOCs) in ambient air and rainwater in a tropical environment: concentrations and temporal and seasonal trends. Chemosphere 78(6):742-751

IAEA, International Atomic Energy Agency (2012) Worldwide and regional laboratory comparison on the determination of organochlorine compounds, polybrominated diphenyl ethers and petroleum hydrocarbons in IAEA-451 Clam (Gafrarium Tumidium) sample, Vienna

IPEN, International POPs Elimination Network (2006) Country situation on persistent organic pollutants (POPs) in India. IPEN http://www.ipen.org. Accessed 5 Oct 2012

Iwata H, Tanabe S, Sakai N, Nishimura A, Tatsukawa R (1994) Geographical distribution of persistent organochlorines in air, water and sediments from Asia and Oceania, and their implications for global redistribution from lower latitudes. Environ Pollut 85(1):15-33

Jaward FM, Zhang G, Nam JJ, Sweetman AJ, Obbard JP, Kobara Y, Jones KC (2005) Passive air sampling of polychlorinated biphenyls, organochlorine compounds, and polybrominated diphenyl ethers across Asia. Environ Sci Technol 39(22):8638-8645

Kang YH, Gonz Y, Li GG (2001) The Study of VOCs in Guanting reservoir and Yonginghe River, China. Acta Soc 21(3):338-343

Klanova J, Cupr P, Holoubek I, Boruvkova J, Pribylova P, Kares R, Tomsej T, Ocelka T (2009) Monitoring of persistent organic pollutants in Africa. Part 1: passive air sampling across the continent in 2008. J Environ Monit 11(11):1952-1963

Kutz FW, Wood PH, Bottimore DP (1991) Organochlorine pesticides and polychlorinated biphenyls in human adipose tissue. Rev Environ Contam Toxicol 120:1-82

Merrington G, Winder L, Parkinson R, Redman M, Winder L (2002) Agricultural pollution: environmental problems and practical solution. Taylor \& Franscis, UK, pp 1-264

Ministry of Agriculture (2008) Central insecticide Board and Registration Committee. Department of Plant Protection and Quarantine. Ministry of Agriculture, India. http://www.india. gov.in/ http://cibrc.nic.in/. Accessed 5 Oct 2012

Mishra K, Sharma RC, Kumar S (2012) Contamination levels and spatial distribution of organochlorine pesticides in soils from India. Ecotoxicol Environ Saf 76(2):215-225

Ozcan S, Aydin ME (2009) Organochlorine pesticides in urban air: concentration, sources, seasonal trends and correlation with meteorological parameters. Clean Soil Air Water 37(4-5): 343-348
Pandey P, Khillare P, Kumar K (2011) Assessment of organochlorine pesticide residues in the surface sediments of River Yamuna in Delhi, India. J Environ Prot 2(5):511-524

Pozo K, Harner T, Wania F, Muir DC, Jones KC, Barrie LA (2006) Toward a global network for persistent organic pollutants in air: results from the GAPS study. Environ Sci Technol 40(16): $4867-4873$

Pozo K, Harner T, Lee SC, Sinha RK, Sengupta B, Loewen M, Geethalakshmi V, Kannan K, Volpi V (2011) Assessing seasonal and spatial trends of persistent organic pollutants (POPs) in Indian agricultural regions using PUF disk passive air samplers. Environ Pollut 159(2):646-653

Sanusi A, Millet M, Mirabel P, Wortham H (1999) Gas-particle partitioning of pesticides in atmospheric samples. Atmos Environ 33(29):4941-4951

Sauret N, Wortham H, Putaud JP, Mirabel P (2008) Study of the effects of environmental parameters on the gas/particle partitioning of current-use pesticides in urban air. Atmos Environ 42(3):544-553

Shoeib M, Harner T (2002) Characterization and comparison of three passive air samplers for persistent organic pollutants. Environ Sci Technol 36(19):4142-4151

Sofuoglu A, Cetin E, Bozacioglu SS, Sener GD, Odabasi M (2004) Short-term variation in ambient concentrations and gas/particle partitioning of organochlorine pesticides in Izmir, Turkey. Atmos Environ 38(27):4483-4493

TNAU, Tamil Nadu Agricultural University (2009) Agriculture policy notes. http://agritech.tnau.ac.in/agriculture/agri_majorareas_ agripolicy\%20notes_\%20eng.pdf. Accessed 5 Oct 2012

Toxic Links Fact Sheet (2011) DDT Loosing in India: alternatives imminent. http://toxicslink.org/docs/Factsheet_38_DDT.pdf. Accessed 5 Oct 2012

UNECE, United Nations Economic Commission for Europe (1998) Protocol on persistent organic pollutants under the 1979 convention on long-range transboundary air pollution. http:// www.chem.unep.ch/gmn/guidanceGPM.pdf (ECE/EB.Air/60). Accessed 5 Oct 2012

USEPA, United State Environment protection agency (2009) Toxicological review of chlordecone (kepone) (CAS No. 143-50-0). In: Support of summary information on the integrated risk information system (IRIS) Washington, DC. EPA/635/R-07/ 004F, www.epa.gov/iris, Accessed 5 Dec 2013

Willett KL, Ulrich EM, Hites A (1998) Differential toxicity and environmental fate of hexachlorocyclohexane isomers. Environ Sci Technol 32(15):2197-2207

Zhang G, Chakraborty P, Li J, Sampathkumar P, Balasubramanian T, Kathiresan K, Takahashi S, Subramanian A, Tanabe S, Jones KC (2008) Passive atmospheric sampling of organochlorine pesticides, polychlorinated biphenyls, and polybrominated diphenyl ethers in urban, rural, and wetland sites along the coastal length of India. Environ Sci Technol 42(22):8218-8223

Zheng X, Chen D, Liu X, Zhou Q, Liu Y, Yang W, Jiang G (2010) Spatial and seasonal variations of organochlorine compounds in air on an urban-rural transect across Tianjin, China. Chemosphere 78(2):92-98 